\title{
Interdisciplinary methodological framework of biomechanics and occupational psychology for MSD prevention
}

Méthodologie interdisciplinaire de prévention des TMS-: association de la Biomécanique et de la Clinique de l'activité

Adriana Savescu, Pascal Simonet, Clarisse Gaudez and Gabriel Fernandez

\section{OpenEdition}

\section{Journals}

\section{Electronic version}

URL: https://journals.openedition.org/activites/5836

DOI: $10.4000 /$ activites.5836

ISSN: $1765-2723$

Publisher

ARPACT - Association Recherches et Pratiques sur les ACTivités

\section{Electronic reference}

Adriana Savescu, Pascal Simonet, Clarisse Gaudez and Gabriel Fernandez, "Interdisciplinary methodological framework of biomechanics and occupational psychology for MSD prevention", Activités [Online], 17-2 | 2020, Online since 15 October 2020, connection on 25 August 2021. URL: http://journals.openedition.org/activites/5836 ; DOI: https://doi.org/10.4000/activites.5836

This text was automatically generated on 25 August 2021.

\section{cc) (†) $\odot$}

Activités est mis à disposition selon les termes de la licence Creative Commons Attribution - Pas d'Utilisation Commerciale - Pas de Modification 4.0 International 


\title{
Interdisciplinary methodological framework of biomechanics and occupational psychology for MSD prevention
}

\author{
Méthodologie interdisciplinaire de prévention des TMS-: association de la \\ Biomécanique et de la Clinique de l'activité
}

Adriana Savescu, Pascal Simonet, Clarisse Gaudez and Gabriel Fernandez

The authors thank Olivier Morel and Gilles Reno for their involvement and their technical and statistical expertise.

\section{Introduction}

1 Musculoskeletal disorders (MSD) are still the most frequent work-related illnesses in different sectors, despite the many actions taken to prevent them. Several literature reviews (Denis, St. Vincent, Jetté, Nastasia, \& Imbeau, 2005; Rivilis et al. , 2008; Silverstein \& Clark, 2004) report on different types of intervention by differentiating them according to the type of transformation that they produce, whether these are changes in techniques, organisation or behaviour. In their bibliographic analysis, Denis et al. (Denis et al., 2005) look into not only the types of transformation achieved, but also the types of action implemented to prevent MSDs. In particular, they detail a widely used type of intervention framework that was the subject of a clear consensus (Aptel, Cail, \& Aublet-Cuvelier, 2014; St-Vincent, Chicoine, \& Beaugrand, 1998) and included three main stages: (1) identifying the issue of MSDs within the company, (2) carrying out a diagnosis of the working environments that are a priority for intervention (description of work, evaluation of risk and identification of their determiners (or factors), (3) overcoming the risk through researching solutions and implementing them. This type of intervention is based on an aetiological model of MSDs that takes 
into account that workers are exposed to different risk factors linked to the organisation of work and recommending, in particular, reducing the exposure of operators to the identified risk factors. Other aetiological types of MSD occurrence (Roquelaure, 2016), influenced by approaches based on theories of the work activity, take into account the active role of the operator, who is no longer considered as suffering from exposure to risk factors, but in the capacity as having an active role on the regulations in their job (Aptel \& Vézina, 2008; Vézina, 2001). These approaches support a mechanism of promoting health that aims to reconcile a logic of reducing exposure with developing options for influencing operators on their working environments. In addition, the mechanism of exposure is supplemented by hypotheses on other psycho-physiopathological mechanisms based on the distinction between "movement" and "gesture" (Bourgeois \& Hubault, 2005; Clot \& Fernandez, 2005; Gaudez \& Aptel, 2008; Tomàs, 2013) by looking beyond the physical aspects of movements to include psychological, educational, cultural and social aspects (Simonet, 2011a). In professional environments, the gesture is always contextualised by the occupation that shapes it and it shapes in return. The gesture is one of the tools used by professionals when working. It is created in the dilemmas and strains of the task, between the different categories of the profession: personal, interpersonal, transpersonal and impersonal ${ }^{1}$ (Simonet \& Clot, 2014). The gesture is also intrinsically social and psychological. It enables the subject to carry out operational actions for the psychological and social situation aimed at others. Therefore, it is part of an individual, collective and organisational history and to carry this out, the subject can make use of a wealth of creativity and ingenuity, depending on the work setting (Pezé, 1998). The study of occupational gestures and their potential development cannot be limited to just effective and operational series of segments. In addition, one of the concerns in preventing MSDs that takes into account these considerations is that of understanding the occupational gestures as they arise and as they are reinvented in their work environment to carry out the activity. The gesture-focused approach questions the practices of actors in occupational health in their capacity of constructing debates that are framed and organised around the questions about the profession within their intervention measures (Caroly et al., 2008; Fernandez, 2009). From this developmental perspective, following which "the human body (is) predisposed to an undefined range of states, from those that are most unfavourable to most favourable to its capacity to act, via the most neutral and indifferent" (Jaquet, 2004), studies in occupational psychology have made it possible to suggest that MSDs largely originate in awkward gestures (Clot \& Fernandez, 2005). They are defined as gestures that are locked in compulsive repetition, regardless of the variety of obstacles encountered in the day-today action of work. The approach chosen by the occupational psychology methodology is that of looking beyond the awkward gestures in the occupation that are trapped in detrimental automatic repetition, with the challenge of examining the likely resources, on the part of the professionals, for transforming it into a motion that is enriched with other options for being carried out (Fernandez, 2004; Simonet \& Caroly, 2008). In addition, the idea followed was that the systems of disrupted and awkward operation hold potential for development in their confrontation with (physical and social) obstacles in the environment (Vygotsky, 1934/1994).

With regard to movement (Gaudez \& Aptel, 2008), it has often been studied individually in a number of works on musculoskeletal disorders, especially to evaluate the biomechanical stress on operators. Movement can be characterised using various 
techniques, such as observation (Brunet \& Riff, 2009) and measuring the muscle activity (by surface electromyography in a non-invasive technique) (Gaudez \& Cail, 2016; Gaudez, Wild, \& Aublet-Cuvelier, 2015). These two techniques can be used in real workplace environments (Gaudez, Bonnet, \& Aublet-Cuvelier, 2013; Savescu et al., 2010) and provide information that presents different levels of detail. The data taken from the surface electromyography provides information on muscle activity. In addition, muscle activity in an identical movement observed may be different without it being possible to identify the reasons that cause this. As a supplement, the analysis of occupational psychology places professionals in a situation in which the gestures and dilemmas of the activity and occupation that they encounter every day can be observed and analysed.

3 Taking into account the approach by analysing the occupational gesture and multifaceted nature of MSDs, the scientific literature encourages a multidisciplinary analysis of the activity and gestures in order to suggest preventative solutions that are better suited to the needs of companies (Vézina, 2001). In reality, despite the efforts made (Plamondon \& Denis, 2008; Savescu \& Cuny-Guerrier, 2015; Thibault, Merlin, \& Garrigou, 2013), progress is still to be made in putting interdisciplinary interventions into practice. In fact, the development of occupational gestures is based, in part, on debates between professionals within their field, but also on debates with the creators of rules that are recommended for carrying out the occupation (Caroly et al., 2008; Massot \& Simonet, 2017). The objective of this article is to show how the analysis of movement can become a tool for enriching the discussion between professionals on the occupational gesture from a perspective of preventing MSDs. This interdisciplinary action (Vinck, 2002) has been led by two teams that want to combine their competencies: occupational psychology and biomechanics (Savescu \& Simonet, 2020). The issue is showing how the biomechanical analysis contributes to the creation of intervention tools implemented in an occupational psychology methodological framework in order to, first of all, allow professionals to better observe their own gesture and then to use this to discuss their work; to move past the obstacle of inevitability; to leave intersubjectivity to, in fine, try other ways of carrying out their occupational gestures and to develop them through "discussed gestures" (Simonet \& Caroly, 2020).

\section{Overall context and methodological framework of the initial request}

4 This intervention responds to the request formulated by a department of preventative medicine that is concerned by the increasing cases of MSDs and complaints associated with these diseases in the field of municipal gravedigging (Van Trier, Simonet, Fernandez, Savescu, \& Gaudez, 2010) ${ }^{2}$. The reported deterioration of the state of health among gravediggers and the increase in the rate of absence due to sick leave complicates the organisation of funeral services. One analysis has been shared between the management of this department and occupational health: "adjusting jobs is difficult because all of the tasks require using your upper body and spine. Furthermore, they disrupt the organisation of work and increase the workload of gravediggers when posts are not adjusted. Thus, putting gravediggers at a higher risk of MSDs." Moving to another role often creates an impasse either because the gravedigger refuses to leave 
their job or because there are no jobs available in another department. The question that then has to be asked is: how can a gravedigger continue in this occupation? In addition, the assessment of actions that have already been taken to prevent MSDs notably reveals a difference between the training on "gestures and postures" provided to gravediggers by a specialist organisation external to the municipality and the complex realities of the profession.

5 The request addressed to the Psychology team of the occupational psychology study was motivated by the desire of OHS professionals, department staff and members of the CHSCT (now the Social and Economic Committee (CSE)) to improve the efficiency of the MSD preventative policy based on an in-depth examination of the complexity of digging graves.

The intervention was carried out over several months. It was primarily structured around:

- three groups of gravediggers at two cemeteries. They were involved in the intervention and represent around a third of the overall workforce at the two cemeteries

- a steering committee bringing together management staff, occupational health professionals and risk prevention professionals and includes participant researchers

- the CHSCT, which was informed at regular intervals about the progress of the intervention and has the opportunity to debate.

7 The organisation of this action makes it possible to distinguish different standard pairings (Oddone et al., 1981) and periods of discussion:

- between gravediggers, without direct participation in the hierarchical structure, on the criteria that marks the quality of a funeral service, in their opinion

- between members of the steering committee ${ }^{3}$ who are in charge of defining the actions for preventative MSDs and questions connected to the organisation of gravedigging work based on different logics (Massot \& Simonet, 2017)

- between the members of the CHSCT supplied by activity reports from participant researchers and occupational physicians

It was after several months of conducting the intervention using the analysis methods in ergonomics and occupational psychology (Simonet, Caroly \& Clot, 2011) that the need to initiate an interdisciplinary cooperation with biomechanical analysis was identified. This new cooperation attempts to respond to the request of gravediggers to better understand the links between the discomfort felt and the execution of a specific gesture: the backward throw.

This gesture is known to be especially delicate: it puts strain on the body and some gravediggers do not want to do it. However, it is essential when digging a grave of $1.50 \mathrm{~m}$ to $2 \mathrm{~m}$ deep. It involves removing the soil from the dug grave (without being able to put it in a nearby wheelbarrow) by throwing it far behind them over their head, over their right or left shoulder depending on their usual method. For gravediggers and their occupational physicians, this gesture is often associated with the discomfort felt in the lower back and shoulders. They expressed a desire to focus the intervention more on examining the complexity of this gesture. 
10 From the perspective of an occupational psychology approach, and at this stage in the intervention, the challenges of interdisciplinary action with biomechanics are primarily:

- from the gravediggers' perspective: equipping them with elements to observe and analyse for a more in-depth, thought-out and disputed examination of the complexity of this gesture in relation to moving their body on the job and their health

- from the perspective of the steering committee and CHSCT members ${ }^{4}$ f fuelling their debates on questions concerning the organisation of work, the choice of equipment, MSD prevention policies based on a more detailed look at the links between the job, the body when working and health.

11 The rest of this article concentrates on the specific ways to implement this interdisciplinary cooperation that expands on the prior analyses and that is in line with the possibilities for gesture development to prevent MSDs.

\section{Methodological framework of the interdisciplinary action}

In order to respond to the new request from gravediggers and their occupational physicians to continue analysing the backward throw gesture, an interdisciplinary intervention methodology was developed. It combines biomechanics and occupational psychology over six stages:

- discussions on the feasibility of cooperation, then creating an intervention protocol between the two teams: the occupational psychology team at the National Conservatory for Arts and Occupations (Conservatoire National d'Arts et Métiers - CNAM) and the biomechanics team of the Working life division at the French National Research and Safety Institute (INRS)

- presenting a protocol for recording muscles stress and calls for gravediggers volunteers to collect data

- collecting and analysing data

- presenting the results of the analysis to volunteer gravediggers and the initiation of opening discussions

- organising personal and cross self-confrontations between volunteer gravediggers based on the results of the biomechanical analysis and video recordings

- multimodal analysis of cross self-confrontations (in-depth analysis of linguistic statements and gestures in self-confrontations).

The researchers in the two teams were actors involved in creating each stage of the methodology. There have been efforts to use the data collection and analysis methods belonging to either team throughout the interdisciplinary methodology.

\subsection{Discussion items in interdisciplinary protocol}

The purpose of the study protocol for this gesture is to produce knowledge about the occupational dilemmas that are often not known and the identified details of which make it possible to think differently about the actions and measures to prevent MSDs. The goal of the biomechanical analysis is to provide information on a blind spot in the occupational psychology analysis: the muscles activity by different ways of performing this gesture. This biomechanical analysis can also make it possible to carry out new 
analyses through personal and cross self-confrontations that are enriched by examining reports between dilemmas of muscle effects and dilemmas of specific activities at work that are issues when working as a gravedigger.

To achieve these objectives with no previous experience in this type of interdisciplinary collaboration, the following points were discussed:

- deciding to work together without reaching an agreement in advance on the use of common scientific vocabulary, for example, on the definition of the concept of a gesture, automation and movement, each taking definitions that belong to different disciplines

- resolving the issue of "biomechanical measurements in laboratories" or "biomechanical measurements in field work" with impacts on carrying out interventions following the option chosen

- confirming the choice of the backward throw gesture out of all the gestures that are discussed between gravediggers, which may be the most effective in the professional opinion of gravediggers, according to the biomechanical analysis

- for the biomechanics team, working towards an objective that goes beyond defining the execution of the movement to impart knowledge to the gravediggers on the intra- and interindividual variability in order to combat the inevitable result of the occupation that "when you're a gravedigger, you're going to get injured"

- for occupational psychology, working on a review of the methodological framework used for gravediggers that is based on, in particular, the results drawn from the biomechanical analysis to guide individual and cross self-confrontations (cf. \$2.5).

\subsection{Presentation of the recording protocol for biomechanical parameters}

The choice of measurements in real work situations was made following a desire to be closer to the conditions of carrying out the activity.

Following discussions between the two research teams and the choice of working on the backward throw gesture (cf. \& 2.1.), precautions have been taken to introduce this new analysis protocol for gravediggers. The objectives of this stage are:

- to undertake to reflect on the debate between the gravediggers on the links between this gesture, which has been identified as complex and occupational issues, which have been questioned when digging a grave

- to present them with a potential protocol to respond to their request for an in-depth study into understanding this gesture

- to mobilise them for use in the recording stage

In addition, the methodology of data recording and analysis of the muscle activity in the upper limbs and back was discussed with the volunteer gravediggers: presentation of techniques (operation and requirements for recording surface electromyography (EMG), video recording) and requirements for data recording, as well as approaches to analysis for this future data within the framework of individual and cross selfconfrontations, which is already known to gravediggers.

\subsection{Biomechanical analysis}

19 The biomechanical analysis given in this article consists of analysing muscle activity in the shoulders and back. It was carried out with a goal of highlighting the intra- and 
interindividual variability around the backward throw gesture and allowing gravediggers to "visualise" and become aware of this variability in order to use it in their discussions at a later stage for the interdisciplinary methodological protocol. Therefore, the challenge is:

- to carry out an intervention and data recording involving a surface electromyography (EMG) in the actual work environment (outside, in a grave) for several gravediggers

- to be able to present biomechanical results in a form that is accessible to gravediggers

- to create a new tool for analysing the activity, which would make it possible to steer dialogues between gravediggers with regard to this hidden dimension to their day-to-day work that involves using their body as a physical tool for carrying out their work.

This decontextualising task makes it possible to create the circumstances for analysing a gesture to lead a debate on the elements that are habitually in the shadow of analyses of working environments.

\subsubsection{Materials and method}

\subsubsection{Participants}

21 Eight volunteer gravediggers participated in this stage of the intervention and their age, height, weight and professional experience, more specifically as a gravedigger, are shown in table 1. Taking into account experience as a gravedigger, of the eight participating gravediggers, four were novices (with experience of between several months and a year) and four were experienced (with experience of between seven and 38 years). Participants in the study were informed in advance about the sequence of the trial, confidentiality of the results and have given their consent to participate.

Table 1. Mean (standard deviation) and range of age, height, weight, general professional experience and experience as a gravedigger of the 8 participants of the study.

Tableau 1. Moyenne (écart type) et étendue de l'âge, de la taille, du poids, de l'expérience professionnelle et de l'expérience comme fossoyeur des 8 participants

\begin{tabular}{llc}
\hline & $\begin{array}{l}\text { Mean } \\
\text { (standard } \\
\text { deviation) }\end{array}$ & Range \\
\hline Age (years) & $33,6(11,6)$ & $23-59$ \\
Height (cm) & $176,4(9)$ & $163-188$ \\
Weight (kg) & $79,2(19,2)$ & $60-124$ \\
Professional experience (years) & $16,4(12,8)$ & $8-45$ \\
\hline Experience as a gravedigger (years) & $10,2(15,2)$ & $0,33-38$ \\
\hline
\end{tabular}

\subsubsection{Conditions of the experiment}

EMG data was recorded while carrying out the actual work of digging a grave. In order to standardise the work environment when recording the backward throws, the following parameters were established: placing a heap of soil behind the workers, digging by a sole gravedigger (with no help from a colleague), presence of formwork to 
hold the removed earth, presence of a path between the container and grave, digging in a particularly grassy cemetery area, in a grave that is $1.5 \mathrm{~m}$ to $2 \mathrm{~m}$ deep with no time constraint (Figure 1). All of these parameters were identified beforehand with the gravediggers during previous analyses of the job and during previous discussions (cf. § 2.2.). This combination of parameters corresponds to a situation that is considered as the most difficult for executing the backward throw gesture.

Figure 1. Example images of the backward throw.

Figure 1. Exemples d'images de jeté arrière

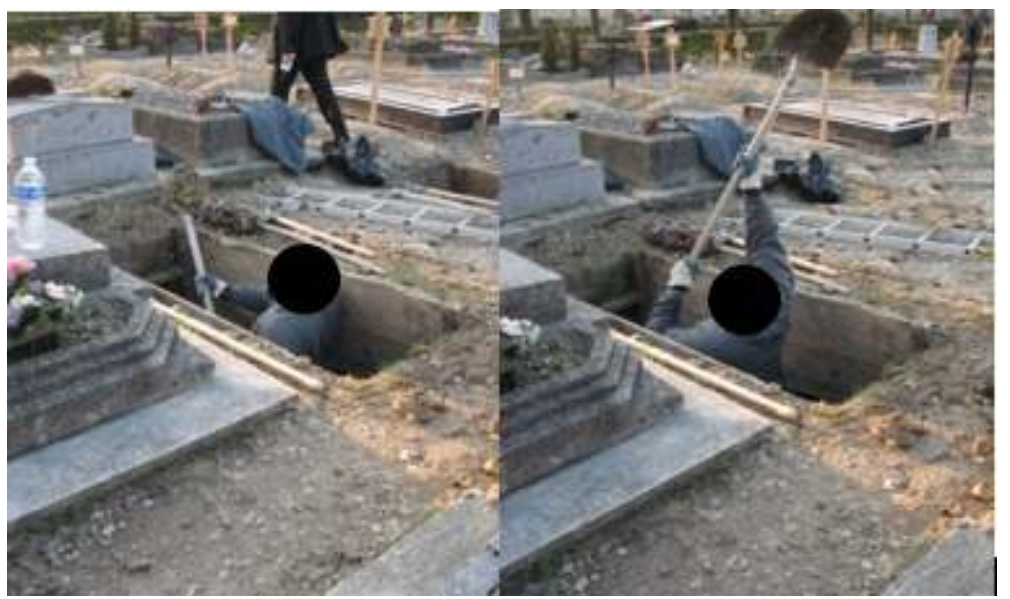

The instruction given to gravediggers is to "work as usual by throwing earth backwards": removing the soil from the dug grave (without being able to putting it in a nearby wheelbarrow) by throwing it far behind them over their head or their right or left shoulder depending on their usual method. During their work when digging, the eight gravediggers carry out the backward throw gesture using each of their usual work tools (fork, draining spade or shovel).

\subsubsection{Process of collecting the muscle activity and video recording}

The participants in the study were equipped with methods for measuring surface muscle activity (surface electromyography (EMG)) using a portable recording system (ME3000 P8-1, Mega Electronics Ltd, Finland) that includes bipolar electrodes with an active surface of $6 \mathrm{~mm}$ (Ambu Blue Sensors $\mathrm{N}-00-\mathrm{S} / 25$, Denmark). The electrodes were attached to the skin $20 \mathrm{~mm}$ apart in line with the recommendations from authors of the SENIAM (SENIAM5, 1997) and Zipp (Zipp, 1982) project. The skin was prepared in advance: cleaned with an antiseptic soap and shaved where the electrodes were placed with a disposable razor to eliminate hair and the superficial part of the stratum corneum of the epidermis. The electrical activity of the following muscles was recorded: right and left anterior deltoid, right and left intermediate deltoid, right and left posterior deltoid, right and left L3 lumbar segment. These muscles were chosen in accordance with those used in the backward throw gesture, which primarily utilises the shoulders and back. Once the data was recorded, each EMG signal was amplified (412 times) and filtered $(5-800 \mathrm{~Hz}$ at a frequency of $1000 \mathrm{~Hz})$. The average root mean square (RMS) for the consecutive intervals of $40 \mathrm{~ms}$ was calculated for each recording.

Each gravedigger was given a brief opportunity to familiarise themselves with the tools in the work environment before the recording was taken for real. ${ }^{5}$ 
In order to standardise the EMG data, several methods were recommended in the literature (Burden, 2010; Fischer, Belbeck, \& Dickerson, 2010; Yang \& Winter, 1983), as well as a variety of tests (Boettcher, Ginn, \& Cathers, 2008; Kelly, Kadrmas, Kirkendall, \& Speer, 1996; Matkowski, Martin, \& Lepers, 2011; McCully, Kumar, Lazarus, \& Karduna, 2005; SENIAM5, 1997). Taking into consideration the discomfort expressed by gravediggers and the study objectives, the standardisation of EMG signals was achieved bilaterally with submaximal efforts. The postures were chosen according to the muscle's primary function and the recommendations in the literature (McCully et al., 2005; SENIAM5, 1997) (Table 2). They are maintained and recorded for a period of $20 \mathrm{~s}$. To record the EMG when resting, the participant sat with their hands on their knees. Standardisation was achieved using the following equation:

$$
E M G_{\text {standardised }}=\left[\left(\mathrm{EMG}_{\text {recorded }}-\mathrm{EMG}_{\text {resting }}\right) /\left(\mathrm{EMG}_{\text {standardised }}-\mathrm{EMG}_{\text {resting }}\right)\right] \mathrm{x} 100
$$

Table 2. EMG normalisation procedure for the recorded muscles.

Tableau 2. Procédure de normalisation des EMG des muscles enregistrés

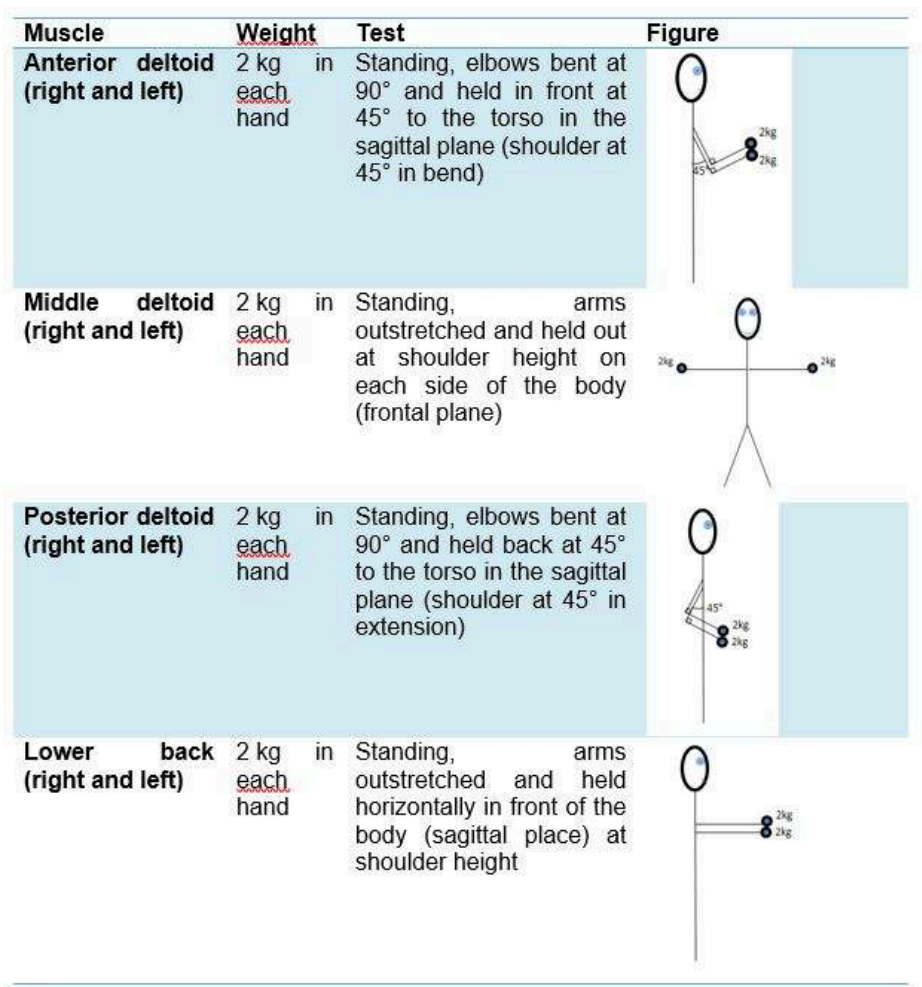

Individual information (height, weight, etc.) was collected to characterise the group of volunteers. The recordings were reported using the characteristics of each individual by standardising muscle activity. This method makes it possible to analyse the intraand interindividual variability.

A video recording that is synchronised with the EMG recording was used. This makes it possible to visualise a posteriori the activity of gravediggers in connection with the EMG signals and to produce a film in preparation for the self-confrontations.

\subsubsection{Analysis of the EMG data}

The backward throw movement is defined as follows (Figure 2): it starts when the tool loaded with earth leaves the floor of the grave and finishes when the earth is thrown 
from the tool and is no longer in contact with the tool. In addition, all other digging actions were removed from the analysis field. One cycle indicates a backward throw movement as defined. The analysis was carried out cycle by cycle and took into account the experience of volunteer gravediggers in this occupation.

Figure 2. Definition of the backward throw movement based on synchronised EMG and video recordings.

Figure 2. Définition d'un mouvement de jeté arrière suivant l'enregistrement synchronisé de l'EMG des muscles et de l'enregistrement vidéo

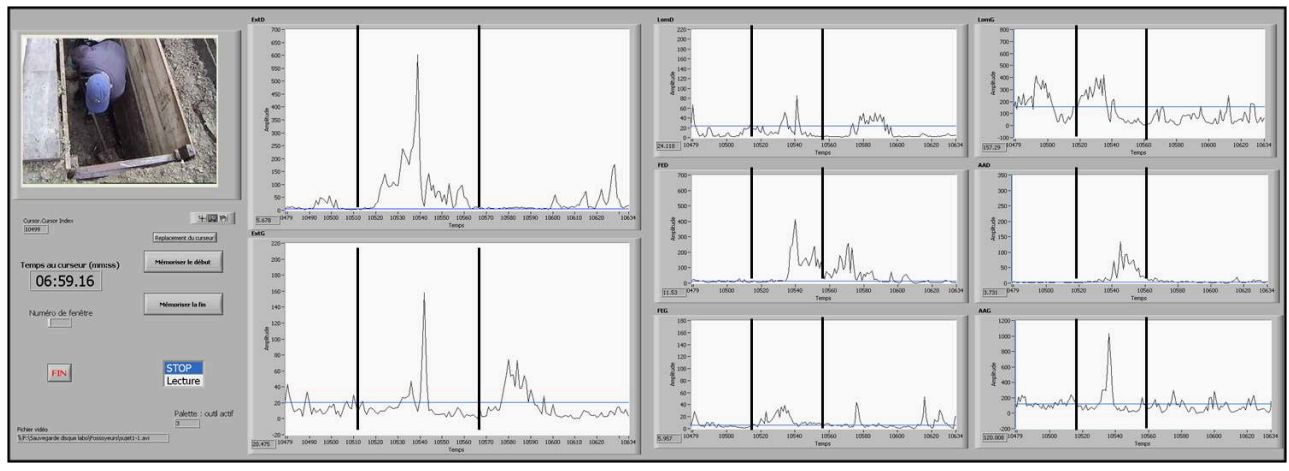

The variables used to analyse a cycle are: the maximum peak (max. EMG) of each of the eight muscles and the duration of the cycle. A comparison was made between the different cycles.

31 The influence of experience (novice/experienced) was analysed by means of a one-way ANOVA analysis that used dependent variables: the maximum EMG peak for each muscle recorded and the duration of the cycle. For the intra-subject variability analysis, a regression analysis was used for the maximum EMG peak in each muscle recorded. For all analyses, the chosen significance level was $\mathrm{p}<0.05$.

\subsubsection{Results of the biomechanical analysis}

32 The analyses showed an average max. EMG that was significantly higher for novices than those with more experience in 7 of the 8 muscles recorded (Figure 3): right anterior deltoid, right lateral deltoid, left posterior deltoid, right lower back, left anterior deltoid, left posterior deltoid, left lower back. For two novices, muscle activity that was much higher than for all eight gravediggers was recorded for the left anterior deltoid muscle and the lower back muscles. For the left middle deltoid, the average max. EMG was significantly higher for those with more experience compared to novices. 
Figure 3. Mean (standard deviation) of maximal EMG for experienced gravediggers (filled bars) and novices (empty bars) for different muscles: right anterior deltoid (DAD), right middle deltoid (DLD), right posterior deltoid (DPD, right lower back (LD), left anterior deltoid (DAG), left middle deltoid (DLG), left posterior deltoid (DPG) and left lower back (LG); ‘**' = significant difference $(p<0.05)$. Figure 3. Moyenne (et écart type) de l'EMG maximal pour les fossoyeurs expérimentés (barres pleines) et les novices (barres vides) des muscles : deltoïde antérieur droit (DAD), deltoïde moyen droit (DLD), deltoïde postérieur gauche (DPD), lombaire droit (LD), deltoïde antérieur gauche (DAG), deltoïde latéral gauche $(D L G)$, deltoïde postérieur gauche $(D P G)$ et lombaire gauche $(L G) ;{ }^{\prime * *^{\prime}}=$ différence significative $(p<0.05)$

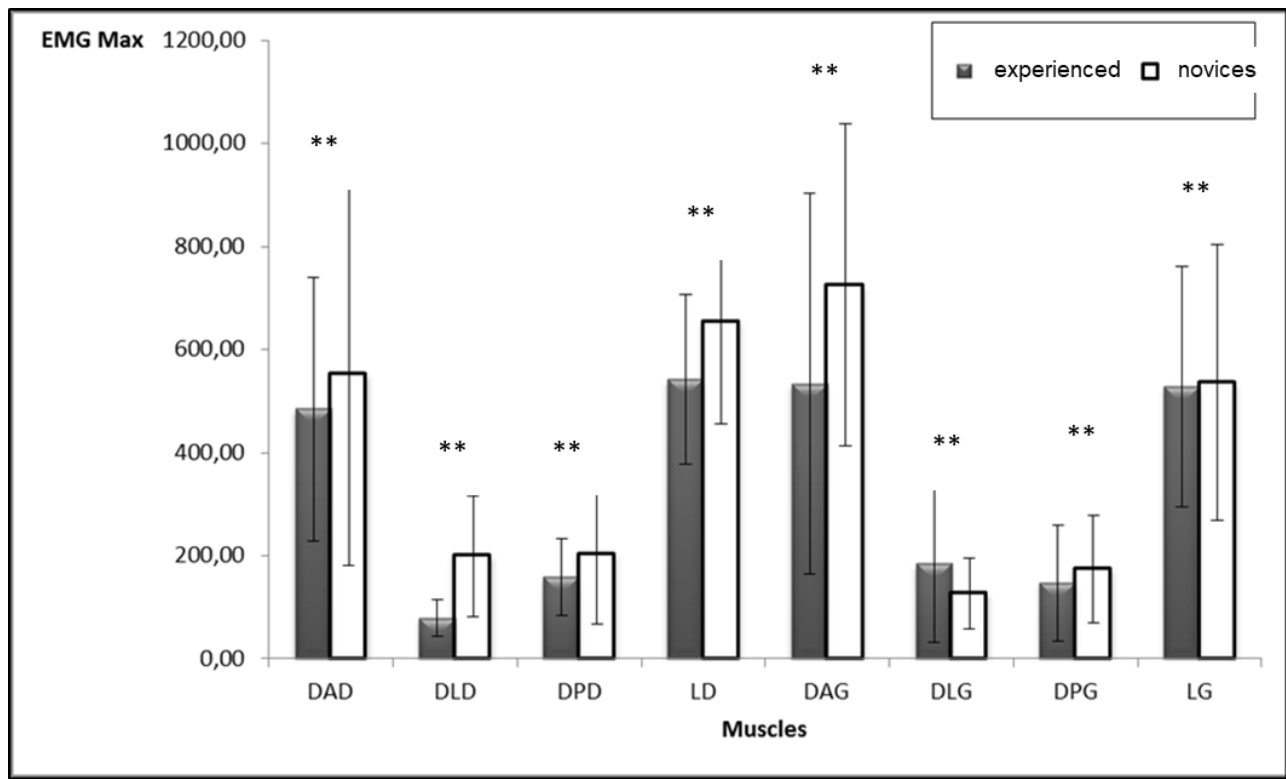

The analysis of the intra-subject variability, which was carried out by regression analysis taking into account the average max. EMG for each muscle and for each gravedigger with each backward throw, showed significant differences (Table 3) between various muscles for novices and those with more experience. These results indicate variability in muscle activity for all volunteer gravediggers, regardless of their experience. Nevertheless, it should be noted that this variability is significant in different muscles (and areas of the body).

Table 3. Regression analysis of maximum EMG for all cycle movements for each muscle and each gravedigger; ${ }^{\prime} \star \star^{\prime}=$ significant difference $(p<0.05) ;^{\prime}{ }^{\prime}{ }^{\prime}=$ non-significant difference $(p>0.05)$.

Tableau 3. Analyse de régression prenant en compte l'EMG max de l'ensemble des cycles pour chaque

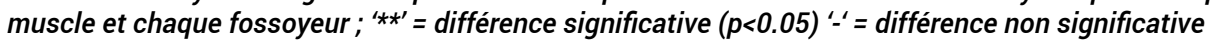
$(p>0.05)$

\begin{tabular}{|c|c|c|c|c|c|c|c|c|c|}
\hline & \multirow[t]{2}{*}{ Experience } & \multicolumn{8}{|c|}{ Muscle } \\
\hline & & $\begin{array}{r}\text { Right } \\
\text { anterior } \\
\text { deltoid }\end{array}$ & $\begin{array}{r}\text { Right } \\
\text { intermed } \\
\text { iate } \\
\text { deltoid }\end{array}$ & $\begin{array}{r}\text { Right } \\
\text { posterior } \\
\text { deltoid }\end{array}$ & $\begin{array}{l}\text { Right } \\
\text { lower } \\
\text { back }\end{array}$ & $\begin{array}{r}\text { Left } \\
\text { anterior } \\
\text { deltoid }\end{array}$ & $\begin{array}{r}\text { Left } \\
\text { intermed } \\
\text { iate } \\
\text { deltoid }\end{array}$ & $\begin{array}{r}\text { Left } \\
\text { posterior } \\
\text { deltoid }\end{array}$ & $\begin{array}{r}\text { Left } \\
\text { lower } \\
\text { back }\end{array}$ \\
\hline Gravedigger 1 & experienced & - & - & $* *$ & $* *$ & - & - & $* *$ & - \\
\hline Gravedigger 2 & novice & - & ** & - & $* *$ & ** & $* *$ & - & $* *$ \\
\hline Gravedigger 3 & experienced & $* *$ & $* *$ & - & $* *$ & - & - & $* *$ & - \\
\hline Gravedigger 4 & experienced & - & - & $* *$ & - & - & $* *$ & - & - \\
\hline Gravedigger 5 & novice & - & - & - & - & $* *$ & $* *$ & - & $* *$ \\
\hline Gravedigger 6 & novice & $* *$ & - & - & - & - & $* *$ & - & - \\
\hline Gravedigger 7 & novice & $* *$ & $* *$ & $* *$ & $* *$ & $* *$ & $* *$ & - & - \\
\hline Gravedigger 8 & experienced & $* *$ & - & $* *$ & $* *$ & - & - & $* *$ & - \\
\hline
\end{tabular}


Taking into account the duration of the cycle, the analyses showed that there was no significant difference between the group of those with more experience and the group of novices (Figure 4). All of the gravediggers completed backward throws between $2 \mathrm{~s}$ and $3.5 \mathrm{~s}$ for an average duration of $2.5 \mathrm{~s}$.

Figure 4. Mean (standard deviation) of cycle time period for experienced gravediggers (filled bars) and novice gravediggers (empty bars).

Figure 4. La moyenne (et l'écart type) de la durée du cycle pour le groupe des expérimentés (barres pleines) et des novices (barres vides)

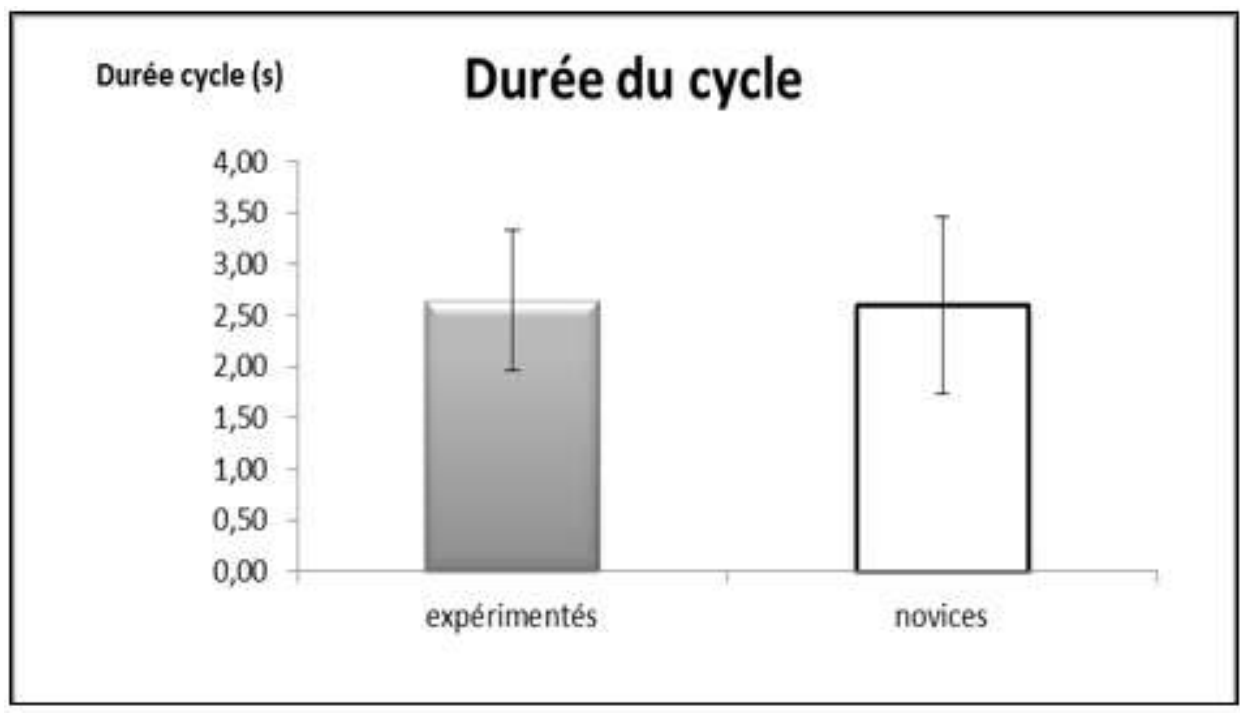

\subsection{Presentation of muscle activity results for all volunteer gravediggers}

Once the muscle activity data has been processed, the results of these analyses were presented by biomechanicians in a comprehensive manner to the eight gravediggers who provided the data. The objectives of this stage were: to provide these results to make gravediggers aware of them and to prepare for the personal and cross selfconfrontation stage. This presentation was preceded by a reminder of the framework in which the data collection was carried out, of the methodology analysis and, in particular, of the definition of the backward throw gesture by the research team (cf. § 2.3.1.4.).

\subsection{Organising individual and cross self-confrontations between participating gravediggers based on the results of the muscle activity analysis}

At the stage of organising the self-confrontations, the challenge was making the results of the muscle activity results accessible to the occupational psychologist researcher and the gravediggers. They should use these as tools to analyse the backward throw gesture from the perspectives of the methodological framework presented in part 1 of the article. 


\subsubsection{Providing technical support in self-confrontations}

\section{(1)} lower back), two ranges of gestures (taken from all of the recorded cycles) were defined taking into account the EMG: a range of gestures that is the least demanding (at least five for each gravedigger) and a range of gestures that is the most demanding (at least five for each gravedigger). A video montage of these cycles was also put together. In this video montage, each cycle was numbered so as to easily see whether a movement was more or less demanding (Figure 5). These elements make up the technical support of the personal and cross self-confrontations performed with the volunteer gravediggers.

Figure 5. Example of presented results including muscular activity (mean EMG) and associated video recordings for different anatomic zones (EP D - red circles = right shoulder; EP G - blue circles $=$ left shoulder; Lomb $\mathrm{D}-$ blue rhomb $=$ right lumbar; Lomb $\mathrm{G}-$ red rhomb = left lumbar). Figure 5. Exemple de montage des résultats de l'analyse des activités musculaires (moyenne EMG) et de la vidéo assiociée des quatre zones anatomiques analysées (EP D : épaule droite, cercle bleu; EP G : épaule gauche, cercle rouge ; Lomb D : lombaire droit, losange bleu ; Lomb G : lombaire gauche, losange rouge).

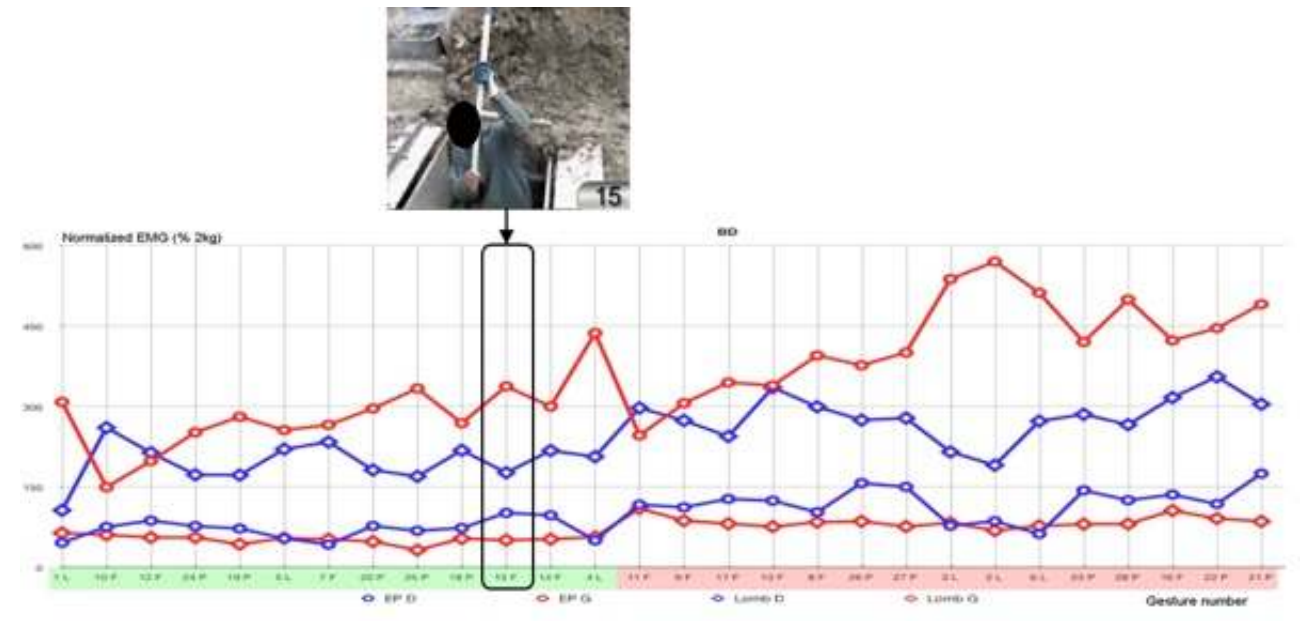

\subsubsection{Carrying out the personal and cross self-confrontations}

The personal self-confrontation took place outside the workspace and aimed to have each gravedigger analyse their own results and their own movements. The personal self-confrontation was carried out according to a specific outline: self-confronted subject/technical supports involved (video montage and graphic representations here)/participant researchers (occupational psychologist and biomechanic). The advice given to the gravediggers was to comment on what they see themselves doing, or not doing, in the video. The gravediggers' comments and exchanges with the participant researcher were recorded on video. In the context of this combined analysis with the muscle activity results, the personal self-confrontation took place in two stages: first, the subject was confronted with their own technical support (EMG analysis + video) and then with the technical support of some of their colleagues with the aim of preparing 
for the following discussion stage between colleagues on the basis of their respective analyses.

The cross self-confrontation took place outside of the workspace and according to a specific outline: two self-confronted subjects/technical supports of each/participant researchers. The pairing of the two self-confronted gravediggers was implemented as follows: the greater the differences in muscle activity between the two gravediggers, the more that participant researchers sought to group them together during the cross self-confrontation, with their permission. The advice given to each party was to comment, alternately, on the video of their colleague present, with each of them having completed the personal self-confrontation experience beforehand. The objectives of this stage were: to provoke a discussion between the gravediggers on their different ways of doing the backward throw movement, thus expanding the expertise of each person through the exchanges built on analysing the details (including muscle activities) of the movements that are the most automatic and invisible to their own eyes, and also to lead the gravediggers to rediscover their professional concerns and the responses to be provided at an individual, collective and organisational level. The subjects' comments were recorded on video with a view of using them, with their permission, alongside their colleagues and members of the steering committee who are the recipients of the questions raised by these analyses.

\subsection{Multimodal analysis of the cross self-confrontations}

41 The following short extract shows how two gravediggers (Figure 6) managed to appropriate the results of the muscle activities analysis, in the form of the technical support, to use them as a focus for discussing their respective ways of executing the backward throw movement. This extract from the cross self-confrontation of two gravediggers (DB and GD) and moderated by the participant researcher in occupational psychology (In) makes it possible to better take into account how each one seeks to resolve the problems encountered in the execution of this movement by trying their colleague's method.

Figure 6. The gravediggers GD and BD showing throwing backwards during crossed confrontations.

Figure 6. Fossoyeurs GD et DB montrant le geste de jeté arrière au collègue lors d'une auto-confrontation croisée

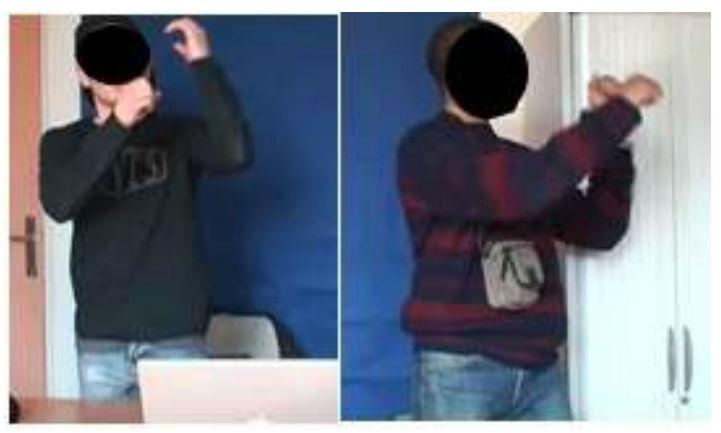


Figure 7. Extract from the cross self-confrontation.

Figure 7. Extrait d'auto-confrontation croisée

In 1 (We see the image of DB digging. GD must comment on what he sees his colleague doing. The researcher asks for his comments.): Do you think he's struggling there in what you see him doing? (...)

DB 2: We should remake a video, I would be in the green from both sides by now.

In 3: (GD smiles at what his colleague just said): that made your colleague smile

GD 4: even as you say, it's the same, huh (1") You still would not be in the green.

In 5: From what you can see your colleague doing, what shouldn't he do in the green?

GD 6: He would be twisted even by changing his legs, I don't know, he still twists because you put yourself like that when you throw like that? (pause 3") Are the legs positioned correctly there?

In 7: Put yourself side on, there

GD 8: Go on (DB gets up) you throw to that side!

DB 9: I have the tool like that

GD 10: Yeah

DB 11: I support and I place it

GD 12: yeah but look at your shoulder (pause 2") It's rounded

DB 13: No, my arm, it's, it stays like that

GD 14: Yeah but you do

DB 15: it isn't

GD 16: that still

DB 17: it's not in the air

GD 18: but even if you're not in the air, you still do it! When you go like that, look, your shoulder doesn't move, I do that and my arm simply slides/try to do the other way around like me, like that

DB 19: ha, no, I do it like you, I still do.

GD 20: ha, okay, there you do, I think that like that, you labour less than the other way, I don't know. (Silence)

The expressions highlighted in bold in this extract (Figure 7) show how the gravediggers and the participant researcher use the technical support shot taken from the muscle activities analyses to stimulate their professional dialogue. All the 
gravediggers confronted with the technical support elements (the video and the electromyographic results categorising the backward throws as the most or least demanding) involve their body in the dialogue to varying degrees, from repeated simulations of studied movement to imitating the colleague's movement (Simonet, 2011a). The production of these physical outputs in a refreshing dialogue among them (Ajuriaguerra, 1962; Bullinger, 2004) even sometimes takes precedence over the production of linguistic statements: we can note it particularly when the words seem to be overly restrictive tools for understanding these "postural-tone" dilemmas of the digging operation and these issues of body placement in the grave that each of them seeks to better capture in the debate.

These operation results lead us to propose a multimodal analysis, by reconciling the works of Cosnier (Cosnier, 1996, 1997) for transcribing the verbal and gesturing argumentative statements and the Benesh rating technique (Mirzabekianz, 2000) for the movement rating carried out during the dialogue. The nature of the appropriation of the results issued from the muscle activities analysis and the video images by the gravediggers led us to question the sensations that each of them seek to experience. It is for this reason that we propose a multimodal analysis of the impressions of this analysis activity by including it in the examination of a relationship between linguistic statements and sentient experiences. This last aspect can be revealed to the participant researcher from a rating technique which enables them to point out that the movements of a few centimetres in the arm, the elbow, the open angle of the shoulder or any other movement of the segments of the body engaged in the imitated movement, redone, open the subject to the experimentation of new sensations. New sensations that also enable them to imagine operating a little differently or affirm their habitual manner of going about their work by trying avenues of execution borrowed from others in the profession. The assessment of the continuum of repetitions of the gesture during the self-confrontation gives us access to the sentient experience in which the gravedigger engages when he resumes his movement after seeing that of his colleague. The assessment also gives partial access to the abundance of different ranges experienced and felt by the gravedigger from one repetition to the other. Therefore, it is the body's engagement in the work that is the subject of the experiment during which the gravediggers engage in a refreshing dialogue stimulated by cross selfconfrontations organised on the basis of biomechanical analyses. This is a dynamic that can allow the creation of a favourable, discussed movement to prevent MSDs (Simonet \& Caroly, 2020).

Finally, in the individual executions of the style which defines their habitual manner of performing their backward throw, each one attempts to find the way to discuss their personal professional problem through that of the others. For example, while the backward throw of GD in an actual work situation is defined by a backward throw sliding the tool handle in his "skilled left hand" (throwing the earth over his left shoulder) and body inclined to the opposite side (contrary to what was said in GD25), the latter, confronted by his colleagues' way of going about it, repeats the alternate backward throws taking care to "stay straight". In this same exchange, DB, whose backward throw style in an actual work situation is defined by a rotation of non-sliding backward throws, through the cross self-confrontation tries the backward throw by sliding the handle of the tool between his hands. 
The usage of each of their bodies in the ordinary work activity and the simulations of the alternative way of doing it by imitating their colleagues' method enabled us to suggest that in these more varied backward throw experiments which provide information for each of them, each one reevaluated their operational and sensorymotor range. This can enable him to rethink the body's overall engagement in the digging activity. This "broadening of the field of actions [...] typical and fundamental characteristic to human development" (Wisner, 1997, p. 250), synonymous with the development of the power to act (Clot, 2008), includes new potential for the execution of movements. It goes without saying that they will be more or less achievable given the varying characteristics of the grave to dig from one time to the other and those of the gravediggers and the organisation of the collective work of the gravediggers.

\section{Results of interdisciplinary action}

In the previous sections, we have detailed the methods and tools involved to explain how the gesture studied at the request of the gravediggers and the occupational physician was performed, recorded, reconstructed and defined by the two researching teams to analyse the demands on muscles and then to equip the personal and cross selfconfrontations of the gravediggers. In this section, we will place more emphasis on the status of the muscle activities analysis as an instrument for developing their occupational gesture in gravedigging activity.

Figure 8. Functional migration of the gesture.

Figure 8. Migration fonctionnelle du geste

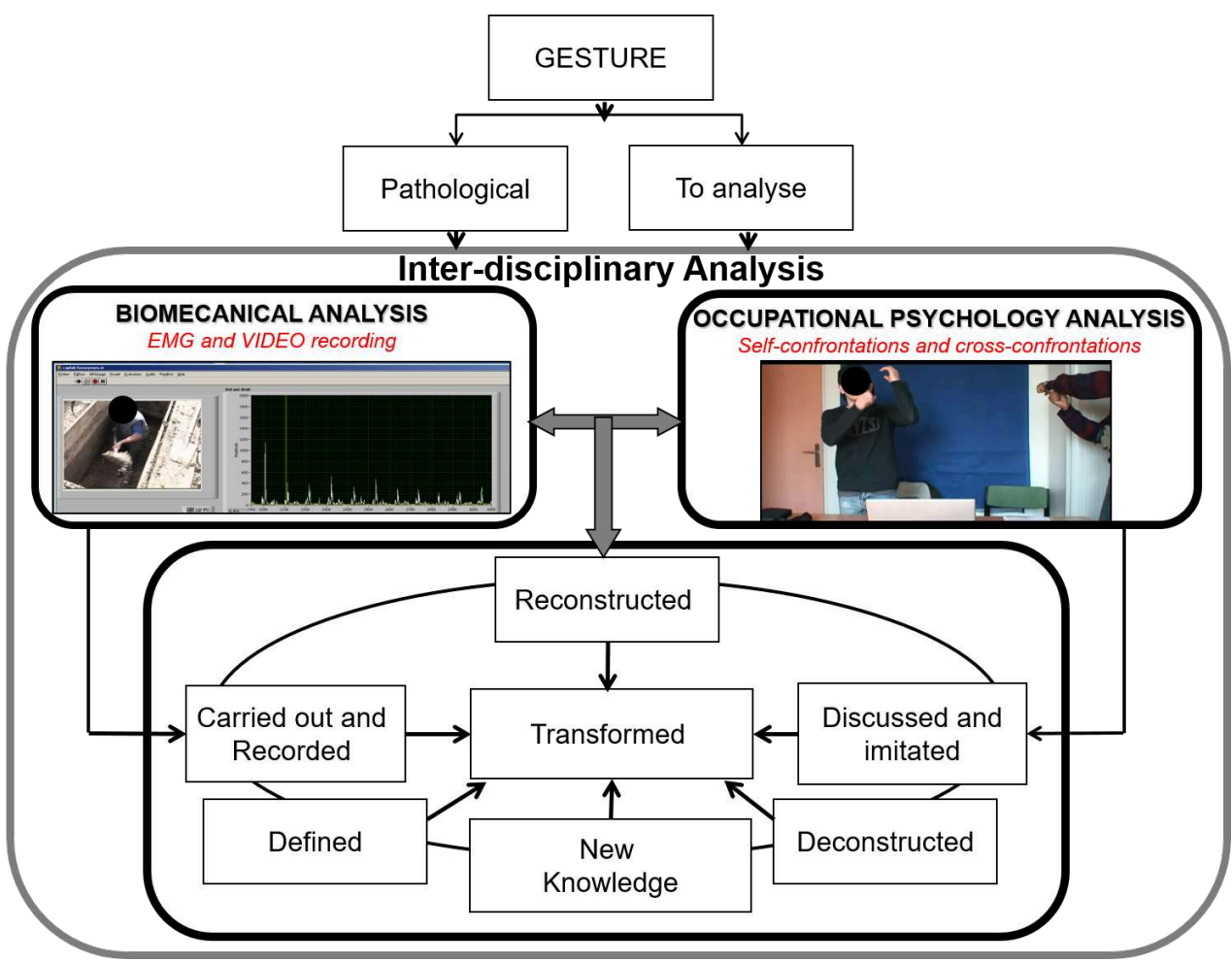

47 This figure shows that the analysis implementing the interdisciplinary methodology enables the gravediggers to examine again, and in another context that is different from that of the actual activity and including the movement analysis (by means of 
muscular activities), the criteria of carrying out a particularly delicate movement to perform, seeing which may be the source of a pathology. Thus, by means of technical support that involves muscle activity analysis results and the synchronous video recording and is used during the personal and/or cross self-confrontations, the backward throw gesture becomes a richer object of discussion from the stylistic variants discussed passing from one context to another in its implementation (observed practical activity, first self-confrontation series, playbacks, muscle activity measurements, new self-confrontation series with the aid of a technical support built on the basis of the muscle activity results). It is in the crossover of these contexts that this gesture becomes more available for professional discussion and in the end, more available to all as an instrument for developing their professional activity. So this backward throw gesture goes from the status of being an at-risk and difficult gesture, which some gravediggers do not want to do even though it is unavoidable in a grave between $1.50 \mathrm{~m}$ and $2 \mathrm{~m}$ deep, to a status of a gesture to study in a more detailed manner, a gesture performed and recorded, a gesture defined by the researchers, a gesture discussed through personal and cross self-confrontations, a gesture broken down into several elements, a gesture enriched by new understandings and finally to the status of a discussed gesture (Simonet \& Caroly) enabling each gravedigger to imagine doing it a little differently in an actual work situation (Figure 8). This circulation of the gesture between these different contexts gives it a different status from one to another: through the analysis of movement, it enables the studied movement to be taken separately from the "identity" of the gravedigger (being the profession) who executes it to then reconnect it, afterwards and in another way, after the debate of which it was the subject and in which the gravedigger repeated it for himself on contact with the others (doing their profession). The interdisciplinary association between the muscle activities and occupational psychology enables the zone for potential development of gesture training to be opened more widely by stimulating their exchanges on their professional concerns.

In the crossover of these contexts where the movement studied was redefined, discussed, imitated, etc., it appears that:

- the dialogue develops in a rotation of linguistic statements and gesturing performances that structure the discussion and stimulate reflections by the gravediggers through the selfconfrontations. In this rotation, the examination of the awkward gesture in one person becomes the means of pushing the limitations of another person's gesture. Indeed, each enriches their corporal experience by discussing the movement of the others: positions and engagement of the body in the grave for digging;

- the work of the body in the activity is stimulated by the confrontation when the individual styles marked by their differences can be discussed through contact with the transpersonal or generic rules of the profession (see: note 1);

- beyond the act of the backward throw gesture itself, this methodological construction which circulates the gesture in its various impersonal, personal, interpersonal and transpersonal registers of the profession (see: note 1) helps to stimulate questions on other organisational dimensions of the gravedigger's profession: the equipment used, the organisation of work in teams, the training of novices and experts, etc. These reflections allow the results presented here to "come to life" in order to integrate them into an overall perspective of preventing MSDs in the steering committee and at the CHSCT (French committee of health and safety and working conditions) (Massot \& Simonet, 2017; Poussin \& Simonet, 2017). 


\section{Discussion}

\subsection{The status of the biomechanical analysis results in the occupational psychology methodology}

\section{provoke a "double stimulation" of the thought and the action (Vygotsky, 1978) in the} methodological context of the self-confrontations. As has already been demonstrated by other works in the perspective of the development of the activity (Engeström \& Sannino, 2013) and by other occupational psychology works open to interdisciplinarity (Fernandez, 2015; Kloetzer, Quillerou-Grivot, \& Simonet, 2015), the experimental context aims to become a context of experimentation in which the worker produces his own tools (films of backward throws, graphics of the most and least uncomfortable backward throws) to set up a favourable framework for analysing the activity (by selfconfrontations here) conducive to the construction of new statements and new psychomotor skills by the subjects. This developmental aim poses technical problems for participant researchers because professionals must appropriate their tools (called occupational psychology artefacts) in order to be able to use them as technical and psychological instruments of their own production. These issues are not new. Vygotsky (Vygotsky, 1927/1999) criticised the psychometric measure when it was limited to measuring the level of psychological development reached from the subject being measured: by reducing it to its current function, it eliminates any developmental perspectives. By supporting this criticism, Vygotsky does not reject in a doctrinaire manner the experimentalism and the quantitative methods. This point is essential to fully understand the meaning of our interdisciplinary action between biomechanics and occupational psychology. Our desire is to overcome the futile divide between qualitative and quantitative methods, as both can be resources for the others when this proves necessary for the advancement of research and action and when the differences between approaches come to be worked on (Savescu \& Simonet, 2020). Based on clinical 
experiences where the subject is put in a position to measure himself against an experimental protocol with a view to deploying the forces of successful compensation of the disease, Vygotsky seeks to make experimental protocols from technical instruments for the development of the subject's activity (Vygotsky, 1978). Our interdisciplinary action is part of this perspective of the organisation of the conditions for the development of the activity and the occupational gesture in activity. However, this perspective has its requirements. In addition, the biomechanical and occupational psychology participant researchers had to make the necessary reciprocal efforts to be involved beyond the addition of skills between several disciplines that are very different from each other that characterises the multidisciplinary action to instead move towards an interdisciplinary action which "supposes a dialogue, an exchange or a confrontation between several disciplines". This is not about a simple juxtaposition, but an interaction and exchange (Savescu \& Simonet, 2020). The disciplines then emerge transformed, even if "the changes are often only peripheral" (Vinck, 2002).

Furthermore, some effects on the occupational psychology methodology framework of the use of the biomechanical analysis can be presented:

- Engagement of the body through simulations and imitations of alternatives for performing the gesture subject to debate in the professional genre. Practical activity cannot be dissociated from activity on oneself in the sense that "the gesture changes, at the same time as the environment, the one who does it." (Wallon, 1942/1970), p. 194).

- Production of artefacts such as the creation of a gesture that is a standard for biomechanical measures, which is necessary for the operation of decontextualisation-recontextualisation of the gesture in the activity ${ }^{7}$ : there is no gesture without action carrying out a practical activity (the digging of a grave) because the gesture performs the action, but the separation of the gesture from the primary action within the framework of another activity (that of the analysis by self-confrontations) is a necessary operation when we want to offer subjects the opportunity to do it again by revisiting the possible ways of transforming their psychomotor and psychosocial engagement in the profession. These newly experienced kinaesthetic sensations are indescribable. It is a part of the movement that escapes language (especially muscle activity) because no part of the movement is conscious (Fernandez, 2015). In the energy displayed by the subjects engaged in these cycles of movement repetitions which fight against their ordinary repetitions at work, the latter transform their relationship to the efficiency of corporal techniques and to the sense of their body's engagement with the work activity (Tomás, Simonet, Clot, \& Fernandez, 2009).

\subsection{The status of the occupational psychology methodology for the biomechanical analysis results}

As an experimental science, biomechanics provides elements of biological plausibility or as part of the ergonomic study led by the ergonomist and often provides metrological information that is useful for understanding or transforming work (Aptel \& Vézina, 2008). In their combined approach, Plamondon \& Denis (Plamondon \& Denis, 2008) highlighted that while ergonomic observations make it possible to identify the elements that appear to best contribute to the efficiency of the gesture, the biomechanical approach helps to quantify the effects on tissue loading and the resulting mechanical work (the movement of body segments). In another study on the use of gestural variability for the prevention of MSDs (Brunet \& Riff, 2009), the authors 
evoke the difficulties encountered for this type of analysis during different methodologies such as:

- the interruption in the operator's work to initiate a discussion on the movement is difficult for cultural reasons, their surprise or their difficulty in talking about "doing",

- the demanding nature of, and the time devoted to, this type of analysis using systematic observation techniques (220 observations) or carrying out impressions of the activity for self-confrontational interviews (based on 180 video recordings of the operator activity).

From the perspective of these difficulties, biomechanical analysis makes it easier to identify different ways to achieve the same movement.

Moreover, in this study, taking into account the variables validated by the literature (Madeleine \& Madsen, 2009; Madeleine, Voigt, \& Mathiassen, 2008; Mathiassen, Möller, \& Forsman, 2003), the biomechanical methodology mainly comes up against the requirements for recording (in the open air and in a grave between $1.50 \mathrm{~m}$ and $2 \mathrm{~m}$ deep) and the presentation of the results for implementing the technical support (see. § 2.5.1.) used during the personal and cross self-confrontations within the occupational psychology methodology framework. Indeed, the biomechanical results must participate in opening and encouraging dialogue between professionals, and not in closing it. The analysis of movement, using electromyography, could have ceased to bring measured inter- and intraindividual variabilities to the understanding of the gravediggers and their chain of command. However, in this interdisciplinary action, the biomechanical results go beyond the status of providing understanding about movement to become the subject of discussion between professionals to allow them to "see" their movement differently and thus modify it. But this change in status is not without its difficulties because it is known that during participatory ergonomic interventions (Van Eerd et al., 2010), the history of the intervention can facilitate or inhibit the course of the current action. Indeed, the gravediggers, who have already participated in the analysis of their activity, could have taken the results of the biomechanical analysis as an absolute truth without being able or willing to discuss it. In this operation, the challenge of biomechanics is to keep two registers: the accuracy of the results and the possibility of the gravediggers discussing them through the technical support provided. Thus, the results presented support the efforts of the gravediggers in a process of breaking down and reshaping the gesture, through the analysis of movement, within work collectives. Variability is therefore conceived as an operator of transformation and health when it is discussed between experts in the profession. It is the development of its own variability that is targeted in this collective dynamic. Thus, when they are developed in the exchange between peers, the dissonances produced by the methodical examination of intra- and interindividual variability feed the dialogue and professional controversy as a resource of the work collective for each one. The variability of the movements and postures of gravediggers, usually examined in terms of the risks to be addressed by the prevention specialist, ends up being considered here as a means of developing new resources for the action of the gravediggers and their health. At the start of the intervention, it is the discourse of inevitability that dominates: "everyone does their own thing and all manners are the same, so there is no point in talking about it", "in any case hurting your back is normal when you are a gravedigger", "we do the same thing". This expression of "everyone works the same", as mentioned in the literature (Brunet \& Riff, 2009), crystallises the feeling of fatalism in the face of MSDs. Under these conditions, can variability serve any 
purpose other than fuelling fatalism on the part of the gravediggers and the futile managerial desire to silence it in favour of so-called good practices provided by training in movements and postures that are far removed from occupational dilemmas (Simonet, 2012)? By fuelling the exchanges between gravediggers, through the acquired authority they have among the personnel responsible for risk prevention, biomechanical analyses help to establish the professional concerns to be resolved in the organisation of work and the need for new preventative actions designed and carried out with the help of field professionals (Massot \& Simonet, 2017). The biomechanics used make it possible to enrich understanding about movement and thus about the studied movement, to revitalise the work collective of the gravediggers and to give the members of the steering committee new understanding of the practical work situation for gravediggers, as well as new reasons for action that allow them to rethink the training policy for the profession, thus modifying their MSD prevention policy (Poussin \& Simonet, 2017; Simonet \& Poussin, 2014a). The results of this study show that the biomechanical analysis, used especially in the MSD prevention approaches that focus on risk reduction (Thibault et al., 2013), can also take part in developmental approaches by highlighting and using gestural variability.

\subsection{Interdisciplinary action methodology for the sustainable prevention of MSDs}

This interdisciplinary action makes it possible to generate conditions conducive to a circularity between thought, language and movement, by creating contexts for the enunciation and comparison of inter- and intraindividual gestural variability. It revitalises the function of the collective as the developmental domain of professional movement by fuelling the comparison with others and its other options of doing and acting. It allows professionals to revisit the most practical work situations and, thus, to rediscover all the depth that goes from impasses to possibilities that have not yet been exploited or considered. Therefore, each of them can observe but also try out the backward throw movement in a different way by re-examining their engagement in this activity of digging a grave. As mentioned in the extract from the cross selfconfrontation between two gravediggers, the repetition of the gestural simulation of one is organised in the repetition of the gestural simulation of the other. The collective is then to be considered here as an instance of deliberation in each of the participants in the action. In this case, the gravediggers also participate in the construction of training content as others have been able to envisage it (Vézina, Prevost, Lajoie, \& Beauchamp, 1999) and in the development of their own professional actions (Clot, Fernandez, \& Scheller, 2007).

The results of this interdisciplinary action should, in our opinion, allow MSD prevention specialists to develop prevention systems based on the goals they want to achieve. They make it possible to rethink the training systems for the professional gesture by going beyond the barrier of inevitability ("we are gravediggers so we have back pain") or the training "in good practices". Other multidisciplinary studies (Plamondon \& Denis, 2008) have highlighted the lack of convergence between the socalled "safety" techniques taught in training programmes and those observed in the field. These authors took up the challenge of taking into account both biomechanical considerations and considerations of work quality and the satisfaction that professionals derive from their work. The results of this study are associated with this 
type of approach and show that the existing approaches to prevention (Denis et al., 2005) can be enriched and must offer the space and time for the continued development of the gesture in the debate built between pairs and also with the other players in prevention and decision makers in the organisation of work. Thus, from a methodological point of view, prevention systems must ensure that these possibilities are organised for professionals to compare their professional actions in discussions between themselves and then with their chain of command and prevention specialists. Hence, the concern is to not confuse systems that open up on the explanation of the gesture already made and those that open up on the experimentation of the possible gesture to be made, while questioning the working conditions in which it is possible to do otherwise.

The results of this action establish a bridge between operators and decision makers in the organisation of work when the professional gesture becomes an object of discussion from different points of view. They are part of a dynamic established in the work group for the sustainable prevention of MSDs as mentioned by Aptel and Vézina (Aptel \& Vézina, 2008).

\section{Conclusion}

The results presented show that the interdisciplinary methodology allows the potential movement development zone to be opened more widely in the activity of the gravediggers by encouraging discussions between professionals. Likewise, the biomechanical analysis has not been exclusively performed in a perspective of new knowledge contribution. The visibility and discussion in the field of inter- and intraindividual variability has broadened the professional environment (chain of command and CHSCT included) (Massot \& Simonet, 2017) to include new forms of prevention actions for MSDs. The occupational psychology methodology involved here has benefitted from the contribution of the biomechanical analysis of the gesture to develop the power of the action from its methodological framework with the collaboration of pairs but also with the adjudicators. As Jacques Leplat urges (Leplat, $2005,2013)$, it would be appropriate in work analysis to give professional gestures their place, training and development more consistently. The prevention of MSDs must also be able to offer the possibility of resuming the proper movement by raising it to the status of a discussed movement that is open to new contexts of its performance both in its training and in its execution. This perspective questions the tools of action and the methodological aim of preventive actions in professional environments. It opens onto the potentially inexhaustible and methodologically prolific issue of interdisciplinary action methods serving the active involvement of professionals and other stakeholders in the field in the sustainable prevention of MSDs. 


\section{BIBLIOGRAPHY}

Ajuriaguerra, J. (1962). Le corps comme relation. Revue suisse de psychologie pure et appliquée, 21, 137-157.

Aptel, M., Cail, F., \& Aublet-Cuvelier, A. (2014). Les troubles musculosquelettiques du membre supérieur. Guide pour les préventeurs. INRS, $94 \mathrm{p}$.

Aptel, M., \& Vézina, N. (2008). Quels modèles pour comprendre et prévenir les TMS ? Pour une approche holistique et dynamique. Paper presented at the $2^{\mathrm{e}}$ Congrès francophone de recherche sur les TMS, Montréal, Canada.

Boettcher, C. E., Ginn, K. A., \& Cathers, I. (2008). Standard maximum isometric voluntary contraction tests for normalizing shoulder muscle EMG. Journal of Orthopaedic Research, December, 1591-1597.

Bourgeois, F., \& Hubault, F. (2005). Prévenir les TMS. De la biomécanique à la revalorisation du travail, l'analyse du geste dans toutes ses dimensions. Activités, 2(1), 20-36. Retrieved from https://journals.openedition.org/activites/1561

Brunet, M., \& Riff, J. (2009). Analyse et exploitation de la variabilité gestuelle dans la prévention des TMS. PISTES, 11

Bullinger, A. (2004). Le développement sensori-moteur de l'enfant et ses avatars. Un parcours de recherche. Ramonville Saint-Agne : ìres

Burden, A. (2010). How should we normalize electromyograms obtained from healthy participants? What we have learned from over 25 years of research. [https://doi.org/10.1016/ j.jelekin.2010.07.004]. Journal of Electromyography and Kinesiology, 20(6), 1023-1035.

Caroly, S., Coutarel, F., Escriva, E., Roquelaure, Y., Schweitzer, J. M., \& Daniellou, F. (2008). La prévention durable des TMS. Quels freins ? Quels leviers d'action? In F. Daniellou (Ed.), Rapport de recherche, PACTE, ANACT, LEEST, Équipe d'Ergonomie Bordeaux.

Clot, Y. (2008). Travail et pouvoir d'agir. Paris, France : PUF.

Clot, Y., Faïta, D., Fernandez, G., \& Scheller, L. (2000). Entretiens en autoconfrontation croisée : une méthode en clinique de l'activité. . PISTES, 2(1). Retrieved from www.pistes.uqam.ca/v2n1/ pdf/v2n1a3.pdf

Clot, Y., \& Fernandez, G. (2005). Analyse psychologique du mouvement : apport à la compréhension des TMS. Activités, 2(2), 68-78. Retrieved from https://journals.openedition.org/ activites $/ 1818$

Clot, Y., Fernandez, G., \& Scheller, L. (2007). Le geste de métier : problèmes de la transmission. Psychologie de l'interaction, 23-24, 109-138.

Clot, Y., \& Simonet, P. (2015). Pouvoirs d'agir et marges de manœuvre. Le Travail Humain, 78(1), 31-52. https://doi.org/10.3917/th.781.0031

Cosnier, J. (1996). Les gestes du dialogue. Psychologie de la motivation, 21, 129-138.

Cosnier, J. (1997). Sémiotique des gestes communicatifs. Nouveaux actes sémiotiques, 52(7-28).

Denis, D., St. Vincent, M., Jetté, C., Nastasia, I., \& Imbeau, D. (2005). Les pratiques d'intervention portant sur la prévention des troubles musculosquelettiques : un bilan critique de la littérature. IRSST. 
Engeström, Y., \& Sannino, A. (2013). La volition et l'agentivité transformatrice : perspective théorique de l'activité Revue internationale du CRIRES : innover dans la tradition de Vygotsky, 1, 4-19.

Fernandez, G. (2004). Développement d'un geste technique. Histoire du freinage en Gare du Nord. PhD, CNAM, Paris.

Fernandez, G. (2009). Soigner le travail. Itinéraires d'un médecin du travail. Paris : Ères.

Fernandez, G. (2015). Gestes, action et analyse du travail. R. Ouvrier-Bonnaz, \& A. Weill-Fassina (Eds.), L'analyse du travail entre ruptures et évolutions (pp. 169-185). Toulouse : Octarès.

Fischer, S. L., Belbeck, A. L., \& Dickerson, C. R. (2010). The influence of providing feedback on force production and within participants reproducibility during maxima voluntary exertions for the anterior deltoid, middle deltoid and infraspinatus. Journal of Electromyography and Kinesiology, $20(1), 68-75$.

Gaudez, C., \& Aptel, M. (2008). Les mécanismes neurophysiologiques du mouvement, base pour la compréhension du geste. Le Travail Humain, 71(4), 385-404.

Gaudez, C., Bonnet, N., \& Aublet-Cuvelier, A. (2013, 28-30 août). Evaluations des astreintes : OREGE et Electromyographie de surface pour évaluer les facteurs de risque biomécaniques en situation réelle de travail. Paper presented at the In Actes du 48e Congrès de la Société d'Ergonomie de Langue Française, « Ergonomie \& Société, Quelles attentes ? Quelles réponses? », Paris.

Gaudez, C., \& Cail, F. (2016). Effects of mouse slant and desktop position on muscular and postural stresses, subject preference and performance in women aged 18-40 years. Ergonomics, 59(11), 1473-1486. https://doi.org/10.1080/00140139.2016.1148783

Gaudez, C., Wild, P., \& Aublet-Cuvelier, A. (2015). A better way of fitting clips? A comparative study with respect to physical workload. Applied Ergonomics, 51, 236-243. doi: https://doi.org/ 10.1016/j.apergo.2015.05.005

Jaquet, C. (2004). L'unité du corps et de l'esprit. Affects, actions et passions chez Spinoza. Paris : PUF. Kelly, B. T., Kadrmas, W. R., Kirkendall, D. T., \& Speer, K. P. (1996). Optimal normalization tests for shoulder muscle activation: An electromyographic study. Journal of Orthopaedic Research, 14(4), 647-653.

Kloetzer, L., Quillerou-Grivot, E., \& Simonet, P. (2015). Engaging workers in WRMSD prevention: Two interdisciplinary case studies in an activity clinic. WORK: A Journal of Prevention, Assessment and Rehabilitation, 51(2), 161-173.

Koechlin, B. (1968). Techniques corporelles et leur notation symbolique. Langages, 10, 36-47. Retrieved from http://www.persee.fr/web/revues/home/prescript/article/ lgge_0458-726X_1968_num_3_10_2547

Leplat, J. (2005). Les automatismes dans l'activité : pour une réhabilitation et un bon usage. Activités, 2(2), 43-68. Retrieved from https://journals.openedition.org/activites/1797

Leplat, J. (2013). Les gestes dans l'activité en situation de travail. PISTES, 15(1). Retrieved from https://pistes.revues.org/2951 https://doi.org/10.4000/pistes.2951

Madeleine, P., \& Madsen, T. M. T. (2009). Changes in the amount and structure of motor variability during a deboning process are associated with work experience and neck-shoulder discomfort. Applied Ergonomics, 40(5), 887-894. https://doi.org/10.1016/j.apergo.2008.12.006

Madeleine, P., Voigt, M., \& Mathiassen, S. E. (2008). The size of cycle-to-cycle variability in biomechanical exposure among butchers performing a standardised cutting task. Ergonomics, 51(7), 1078-1095. https://doi.org/10.1080/00140130801958659 
Massot, C., \& Simonet, P. (2017). Intervenir dans l'entreprise pour soutenir la discussion sur le travail comme moyen de transformation. PISTES, 19(3). Retrieved from http:// journals.openedition.org/pistes/5491; https://doi.org/10.4000/pistes.5491

Mathiassen, S. E., Möller, T., \& Forsman, M. (2003). Variability in mechanical exposure within and between individuals performing a highly constrained industrial work task. Ergonomics, 46(8), 800-824. https://doi.org/10.1080/0014013031000090125

Matkowski, B., Martin, A., \& Lepers, R. (2011). Comparison of maximal unilateral versus bilateral voluntary contraction force. European Journal of Applied Physiology, 111(8), 1571-1578. https:// doi.org/10.1007/s00421-010-1775-1

McCully, S. P., Kumar, N., Lazarus, M. D., \& Karduna, A. R. (2005). Internal and external rotation of the shoulder: Effects of plane, end-range determination, and scapular motion. Journal of Shoulder and Elbow Surgery, 14(6), 602-610.

Mirzabekianz, E. (2000). Grammaire de la notation Benesh. Manuel élémentaire. Cahiers de pédagogie : Pantin : Ecole Nationale de Danse.

Oddone, I., Re, A., \& Briante, G. (1981). Redécouvrir l'expérience ouvrière. Vers une autre psychologie du travail ? Paris : Éditions sociales

Pezé, M. (1998). Les athlètes du quotidien : approche psychosomatique et psychodynamique des TMS. In ANACT (Ed.), TMS et évolution des conditions de travail. Les actes du séminaire Paris 98 (pp. 63-70). Retrieved from https://www.anact.fr/tms-et-evolution-des-conditions-de-travailseminaire-paris-1998.

Plamondon, A., \& Denis, D. (2008). Manutention : intérêt d'une approche conjointe ergonomiebiomécanique dans la compréhension du geste. Paper presented at the $2^{\mathrm{e}}$ Congrès francophone sur les troubles musculosquelettiques (TMS), Montréal, Canada.

Poussin, N., \& Simonet, P. (2017). La formalisation d'un répertoire des gestes de métier comme instrument de l'intervention du clinicien de l'activité : une question de recherche. In A.-

L. Ulmann, A. Weill-Fassina, \& T.H. Benchekroun (Eds.), Intervenir. Histoires, recherches, pratiques. Toulouse : Octarès Éditions.

Rivilis, I., Van Eerd, D., Cullen, K., Cole, D. C., Irvin, E., Tyson, J., \& Mahood, Q. (2008).

Effectiveness of participatory ergonomic interventions on health outcomes: A systematic review. Applied Ergonomics, 39(3), 342-358.

Roquelaure, Y. (2016). Promoting a Shared Representation of Workers' Activities to Improve Integrated Prevention of Work-Related Musculoskeletal Disorders. Safety and Health at Work, 7(2), 171-174. doi: https://doi.org/10.1016/j.shaw.2016.02.001

Savescu, A., \& Cuny-Guerrier, A. (2015). Multidisciplinary analysis of risk factors of MSD in meat cutting: the issue of organizing knife maintenance. Paper presented at the 19th Triennial Congress of the International Ergonomics Association, Melbourne, Australia.

Savescu, A., Gaudez, C., Aublet-Cuvelier, A., Simonet, P., Fernandez, G., Van-Trier, M., \& Clot, Y. (2010). Biomechanical metrology: a support in occupational controversies. Paper presented the PREMUS, Angers, France.

Savescu, A. \& Simonet, P. (2020). Pourquoi et comment associer la mesure biomécanique au cadre d'intervention de la clinique de l'activité dans une action de prévention des TMS ?, SELF2020, Paris, France 
SENIAM5. (1997). The state of the art of sensors and sensor placement procedures for surface electromyography. A proposal for sensor placement procedures SENIAM project. In H. J. Hermens \& B. Freriks (Eds.), Copyright 1997 Roessing Research and Development

Silverstein, B., \& Clark, R. (2004). Interventions to reduce work-related musculoskeletal disorders. Journal of Electromyography and Kinesiology, 14(1), 135-152. https://doi.org/10.1016/ j.jelekin.2003.09.023

Simonet, P. (2009). L'examen méthodique d'un geste de métier pour une prévention durable des TMS : une intervention en clinique de l'activité. PISTES, 11(2). Retrieved from pistes website : www.pistes.uqam.ca

Simonet, P. (2011). L'hypo socialisation du mouvement. Prévention durable des troubles musculosquelettiques chez des fossoyeurs municipaux. PhD, Paris : CNAM.

Simonet, P. (2012). La formation du geste entre standardisation et tensions du métier. In B. M. B. Prot (Ed.), Développer le pouvoir d'apprendre : pour une critique de la transmission en éducation et en formation (pp. 66-75). Bologne : TAO Digital Library.

Simonet, P., \& Caroly, S. (2008). Le développement des automatismes comme conception du geste professionnel pour une prévention durable des TMS. Paper presented at the $43^{\mathrm{e}}$ congrès de la Société d'Ergonomie de Langue Française, Ajaccio, France.

Simonet, P., \& Caroly, S., (2020). Geste dialogué et prévention des TMS. Le Travail Humain, 83(1), 1-32. https://doi.org/10.3917/th.831.0001.

Simonet, P., Caroly, S., \& Clot, Y. (2011). Méthodes d'observation de l'activité de travail et prévention durable des TMS : action et discussion interdisciplinaire entre clinique de l'activité et ergonomie. Activités, 8(1). https://doi.org/10.4000/activites.2481.

Simonet, P., \& Clot, Y. (2014). Qualité du travail, santé et clinique de l'activité. Méthode pour l'action. In E. Masson (Ed.), Encyclopédie médicochirurgicale, Pathologie professionnelle et de l'environnement. Paris.

Simonet, P., \& Poussin, N. (2014). La socialisation des gestes de métier : un enjeu de santé au travail qui interroge la formation. Revue éducation permanente, hors série AFPA Les synergies travailformation, 127-135.

Simonet, P., Savescu, A., Van Trier, M., Gaudez, C., \& Aublet-Cuvelier, A. (2011). La

pluridisciplinarité au service de la prévention des TMS : quand l'association entre psychologie du travail et biomécanique devient, pour les professionnels, support d'analyse des gestes de métier. from INRIA www.hal.inria.fr

St-Vincent, M., Chicoine, D., \& Beaugrand, S. (1998). Validation of a participatory ergonomic process in two plants in the electrical sector. International Journal of Industrial Ergonomics, 21(1), 11-21. doi : https://doi.org/10.1016/S0169-8141(97)00021-8

Thibault, J.-F., Merlin, X., \& Garrigou, A. (2013). De la production à l'usage de la mesure, quelle appropriation par deux entreprises industrielles ? Pour quelle prévention des TMS ? Pistes, 15(2). Retrieved from www.pistes.uqam.ca

Tomàs, J.-L. (2013). L'analyse psychologique du développement des gestes professionnels : une perspective pour la prévention des TMS ? Perspectives interdisciplinaires sur le travail et la santé, Pistes, 15(1).

Tomás, J.-L., Simonet, P., Clot, Y., \& Fernandez, G. (2009). Le corps : l'œuvre du collectif de travail. Corps, 6, 23-30. 
Van Eerd, D., Cole, D., Irvin, E., Mahood, Q., Keown, K., Theberge, N., .Village, J., St Vincent, M., \& Cullen, K.L. (2010). Process and implementation of participatory ergonomic interventions: a systematic review. Ergonomics, 53(10), 1153-1166. https://doi.org/10.1080/00140139.2010.513452

Van Trier, M., Simonet, P., Fernandez, G., Savescu, A., \& Gaudez, C. (2010). Prévention durable des TMS chez des fossoyeurs de la ville de Paris. Paper presented at the $31^{\mathrm{e}}$ Congrès National de Médecine et Santé au Travail, Toulouse, France.

Vézina, N. (2001). La pratique de l'ergonomie face aux TMS : ouverture à l'interdisciplinarité. Paper presented at the Société d'Ergonomie de Langue Française-Association Canadienne d'Ergonomie (SELF-ACE), Monréal, Canada.

Vézina, N., Prevost, J., Lajoie, A., \& Beauchamp, Y. (1999). Elaboration d'une formation à l'affilage des couteaux : Le travail d'un collectif, travailleurs et ergonomes. Pistes, 1(1). Retrieved from http://www.pistes.uqam.ca.

Vinck, D. (2002). Fonctions et modèles pour l'interdisciplinarité en ergonomie. Performances humaines et techniques, 5, 7-13.

Vygotski, L. (1927/1999). La signification historique de la crise en psychologie. Neufchâtel.

Vygotski, L. (1934/1994). Défectologie et déficience mentale. Neuchâtel : Delachaux et Niestlé.

Vygotski, L. (1978). Mind in society. The development of higher psychological process. Cambridge \& London : Harvard University Press.

Vygotsky, L. S. (1997). The instrumental method in psychology. The collected works of L. S. Vygotsky. vol. 3. Problems of the theory and history of psychology. New York : Plenum.

Wallon, H. (1942/1970). De l'acte à la pensée. Paris : Flammarion.

Wisner, A. (1997). Aspects psychologiques de l'anthropotechnologie. Le Travail Humain, 60(3), 229-254.

Yang, J. F., \& Winter, D. A. (1983). Electromyography reliability in maximal and submaximal isometric contractions. Archives of Physical Medicine and Rehabilitation 64, 417-420.

Zipp, P. (1982). Recommendations for the standardization of lead positions in surface electromyography. European Journal of Applied Physiology, 50, 41-45.

\section{NOTES}

1. In the workplace, personal gesture is still aimed at colleagues who are the focus of agreed efforts. In this respect, the occupation is interpersonal. Therefore, it survives, or disappears, thanks to all of the professionals who share their personal and interpersonal exchanges on what needs to be done or improved and what should be continued or not. It does not exist only and entirely in the present situation of activities shared in the circumstances: it is also the history and collective memory that gives each respondent their response in the present and "to see what is coming" in the future. This memory of the profession is transpersonal, as no-one owns it. It is a collective piano made up of gestures and words, on which each subject plays their own tune, as the professional aspect is stylised individually by each person. However, the profession also exists in an impersonal form, recorded in the recommended official functions: a career, retirement, tasks, a status, training, evaluation and recruitment criteria, standard performance indicators. This impersonal occupation is essential in psychological terms to imagine what could be and what could be done beyond what has already been achieved. Strains weave in and out of this structure, sometimes until it comes to a head (Simonet \& Clot, 2014b). 
2. We have put in action a research intervention, which we have already been able to use as support in discussions on various themes of intervention and research linked to preventing MSDs (Simonet, 2009; Simonet, Savescu, Van Trier, Gaudez, \& Aublet-Cuvelier, 2011b) and, more generally, health and transforming the organisation of work (Massot \& Simonet, 2017; Poussin \& Simonet, 2017; Simonet \& Clot, 2014b). In this article, we will pay particular attention to the interdisciplinary cooperation between the biomechanical analysis and the occupational psychology methodological framework in the history of this intervention (Savescu et al., 2010; Simonet et al., 2011b) but also in an ongoing scientific dialogue (Clot \& Fernandez, 2005).

3. A steering committee that is led by the head of the cemetery department brings together management staff, occupational health professionals and risk prevention professionals and participant researchers.

4. The assessment of actions that have already been taken with regard to prevention highlighted in particular a difference between the training on "gestures and postures" provided to gravediggers by a specialist organisation external to the municipality and the realities of the profession. Lastly, this intervention made it possible to reiterate the question of using a mechanical digger in cemeteries for decision makers in the steering committee and, at their request, a new internal training measure that was designed alongside the gravediggers was started by the CHSCT.

5. This period allowed the volunteer participants to ask any questions they had about the measurement methods. Furthermore, they were encouraged to stop participating if they felt any particular discomfort.

6. By following Cosnier, for whom "lively discourse is the product of a talking body" (Cosnier, 1996), it appeared necessary to us to make the links between the sensory-motor experiences and argument exchanges visible in the course of the dialogue without proposing either a classification of gestures, the multiple limitations of which have been known for a long time, (Koechlin, 1968) or even a particular semiotic theory of the gesture, irrelevant to the argumentative activity.

7. This operation of decontextualising the gesture from ordinary action is an avenue of research and action that questions the links between gesture, action and work analysis (Fernandez, 2015). We recall that this backward throw gesture performed in the cemetery is presented again but in a distorted form by the images of the video which present a series of backward throws joined together after having been defined by a beginning and an end, eliminating a whole part of the events of actual work activity. However, this transformation of reality was necessary in this system. It sought to focus the attention of the gravediggers on the execution of this movement and to provoke in them a more refined level of observation, astonishment and questioning. The thoroughly examined backward throw gradually became the object of the dialogue between the two professionals and a means of debate to discuss the comparative merits of the way in which each one performs it and beyond the engagement of their body in the digging activity while experiencing new kinaesthetic sensations.

\section{ABSTRACTS}

In France and globally, musculoskeletal disorders (MSD) remain the most widespread occupational diseases. The scientific literature has established that links exist between occurrence of MSD and the professional gesture. The aim of this paper is to analyse how an 
intervention was conducted within the general methodological framework of occupational psychology using activity clinical research based on professional gesture analysis and it has enjoyed interdisciplinary co-operation with biomechanics. The interdisciplinary methodology implemented with eight gravediggers was based on different steps including a detailed analysis of the muscular activity of the shoulder and back muscles. The results show that the presented methodology allows opening more widely the potential development zone of the gesture in the gravediggers' activity by stimulating their professional discussions. The visibility and discussion in the profession of inter- and intra-individual variability has opened up the professional world to new forms of MSD prevention actions.

En France et à l'international, les troubles musculo-squelettiques (TMS) restent les maladies professionnelles les plus répandues. La littérature scientifique a établi l'existence de liens entre la survenue des TMS et la réalisation des gestes en situation de travail. L'objectif de cet article est de montrer comment l'analyse biomécanique participe à la création d'outils d'intervention mis en œuvre dans un cadre méthodologique en clinique de l'activité dans une optique de prévention des TMS se basant sur l'analyse du geste. La méthodologie interdisciplinaire mise en œuvre auprès de huit fossoyeurs comprend plusieurs étapes incluant une analyse de l'activité musculaire des muscles de l'épaule et du dos laquelle est utilisée comme support à des autoconfrontations. Les résultats montrent que la méthodologie interdisciplinaire permet d'ouvrir plus largement la zone de développement potentiel du geste dans l'activité des fossoyeurs en stimulant leurs discussions professionnelles. La mise en visibilité et en discussion dans le métier de la variabilité inter et intra-individuelle de réalisation d'un même geste au contact des questions concrètes de travail a ouvert le milieu professionnel vers de nouvelles formes d'actions de prévention des TMS dans l'organisation prescrite du travail.

\section{INDEX}

Mots-clés: geste, biomécanique, clinique de l'activité, méthodologie, prévention, troubles musculosquelettiques

Keywords: gesture, biomechanics, occupational psychology, methodology, prevention, musculoskeletal disorders

\section{AUTHORS}

\section{ADRIANA SAVESCU}

Laboratoire Physiologie-Mouvement-Travail, French National Research and Safety Institute, CS 60027, 54519 Vandoeuvre-lès-Nancy Cedex, France adriana.savescu@inrs.fr

\section{PASCAL SIMONET}

Centre de Recherche en Éducation de Nantes (CREN, EA 2661), University of Nantes, BP 81227, 44312 Nantes Cedex 3

pascal.simonet@univ-nantes.fr

\section{CLARISSE GAUDEZ}

Laboratoire Physiologie-Mouvement-Travail, French National Research and Safety Institute, CS 60027, 54519 Vandoeuvre-lès-Nancy Cedex, France 


\section{GABRIEL FERNANDEZ}

Équipe Psychologie du travail et clinique de l'activité, Centre de recherche sur le travail et le développement (CRTD, EA 4132), Conservatoire national des arts et métiers, 41, rue Gay Lussac, 75005, Paris. 